\title{
INTEGRATING TWO-STAGE UP-FLOW ANAEROBIC SLUDGE BLANKET WITH A SINGLE-STAGE AEROBIC PACKED-BED REACTORFOR RAW PALM OIL MILL EFFLUENT TREATMENT
}

\author{
Khairunnisa Abdul Halim, Ee Ling Yong* \\ Department of Environmental Engineering, Faculty of Civil Engineering, Universiti Teknologi Malaysia, 81310 UTM Johor Bharu, Johor, Malaysia. \\ *Corresponding Author email: eeling@utm.my
}

This is an open access article distributed under the Creative Commons Attribution License, which permits unrestricted use, distribution, and reproduction in any medium, provided the original work is properly cited.

\section{ARTICLE DETAILS}

\section{Article History:}

Received 12 November 2017 Accepted 12 December 2017 Available online 1 January 2018

\section{ABSTRACT}

Annually, enormous amount of palm oil mill effluent (POME) ranging between 56.58 to $70.55 \mathrm{million}^{3}$ are producedduring the production of palm oil. Its acidic and high organic loading characteristics can cause severe water pollution if discharged without proper treatment. In Malaysia, most oil palm production mills adopted ponding treatment system. However, this treatment requires high retention time and large build area. Thus, the treatment paradigm has shifted tointegrated high rate bioreactors by coupling anaerobic and aerobic processesdue to the incompetency of the conventional treatment in complying the standard effluent discharged outlined by the Department of Environment.Despite the outstanding treatment performance exhibited by this bioreactor, diluted POME was used in almost all previous studies instead of fresh raw POME. Therefore, the researched bioreactors may not be as efficient in real application. This present study aimed to employ the principle of two-stage anaerobic process followed by a single stage aerobic process for the treatment of fresh raw POME, in whicha two-stage upflow anaerobic sludge blanket digester was integrated with a single-stage anaerobic packed bed reactor. This is to ensure the lignocellulosic components will be broken down into simpler organic compounds in the first stage anaerobic bioreactor followed by their reduction in the second stage anaerobic and single stage aerobic bioreactors.With this, the potential mechanical problems and inhibition on the operational interference of the currently available integrated system is rectified. Thus, the overall performance can be enhanced.The treatment efficiency of this system was examined by evaluating the removal of several important parameters, namely chemical oxygen demand (COD) and sludge reduction reported in terms of total suspended solids (TSS). Throughout the 150 days of operation, approximately $93 \%$ and $55 \%$ of reduction were observed for COD and TSS, respectively, suggesting this integrated system was competent in treating high strength wastewater.Nonetheless, further research need to be made to ensure the stability consistency and feasibility of this integrated system.

raw palm oil mill effluent, two-stage anaerobic, aerobic, chemical oxygen demand (COD), total suspended solid (TSS).

\section{INTRODUCTION}

Palm oil industry is one of the largest agricultural industries in Malaysia where it accounts for the annual production output of approximately 17 million tonnes of crude palm oil (CPO) based on Malaysia Palm Oil Board (MPOB) report of 2016 [1]. The huge production of the output has indirectly caused the increase in the amount of waste that need to be managed, especially POME. Owing to the nature of POME that has acidic $\mathrm{pH}$ and contains high concentration of organic contaminants, a proper waste management is required to prevent water pollution in the water bodies.

POME preference that has high concentrations of organic contaminants and biodegradable, best to be treated biologically through anaerobic process. Generally, the anaerobic ponding system has been employed conventionally for decades, where almost $80 \%$ of the palm oil millers still persist with this method, due to low cost and low manpower needed. However, long retention time and large treatment area interests the millers to start investing on the anaerobic digestion, and widely explored by the scholars. Nevertheless, implementation of anaerobic process alone would hardly produce effluents that comply to the standard discharged limit outlined by the Department of Environmental (DOE). Due to the limitations of the process, the researchers have shifted the paradigm of the treatment technologies towards integrated high-rate bioreactors, by assimilating the anaerobic and aerobic process, to enhance the performance of the treatment as well as produce better quality of effluents [2-4].
Few studies have been conducted on the employment of an integrated anaerobic-aerobic system in treating various types of wastewater, and show an excellent performance $[2,3,5,6]$. Chan and fellow associates proved that combination of the anaerobic and aerobic processes in the same reactor attained high removal of organic loadings with 95\% of COD removal at high loading rate of $0.5 \mathrm{~g}-\mathrm{COD} / \mathrm{L} /$ day [2]. However, most of the researchers tend to use diluted POME for their studies, to prevent pumps clogging [2,7-9]. This caused the concentrations of organic loadings and cellulosic compounds were reduced apparently. Meanwhile, the high ratio of lignin to cellulose compounds contains in fresh POME inhibits the performance of the integrated system due to degradation difficulties. Thus, due to that the real application of the integrated system for POME treatment somehow were doubted.

In order to overcome the shortcomings of the currently studied integrated treatment system for fresh POME, researchers started to introduce the principle of multi-stage anaerobic digestion to enhance the performance of the contaminant removal via two-stage anaerobic digestion system [1013]. On top of that, the lignocellulosic compounds are believed would be broken down in the first-stage of anaerobic digester, and degraded to the simpler compound in the following anaerobic digester. Furthermore, the principle of two-stage anaerobic process would enhance the conversion of substrate, boost the efficiency of COD removal and energy recovery as well as has been proven to be competent in treating various industrial wastewater including oil-rich waste such as POME [14-16].

Thus, in this study the principle of coupled two-stage anaerobic and aerobic process was introduced to treat the fresh POME. The purpose of 
this study was to investigate the performance of the integrated two-stage up-flow anaerobic sludge blanket (UASB) with a single-stage packed bed aerobic bioreactor in treating raw POME treatment, which focusing on chemical oxygen demand (COD) and total suspended solid (TSS) reduction.

\section{MATERIALS AND METHODS}

\subsection{Seed sludge preparation}

Sludge collected from the facultative pond treating POME of Felda Bukit Besar, Wilayah Bukit Besar, Johor, Malaysia was used as a seed sludge for all bioreactors in this study. The acclimatized sludge was operated by discharging half volume of cultured broth and refilled to the original volume of the reactor with the addition of: fresh POME (for the AD1); POME discharged from AD1 and aerobic reactor with ratio of 1:1 (for the AD2); and POME discharged from AD2 (for the aerobic reactor). Upon feeding the sample into the AD1 and AD2 reactor, the nitrogen gas was purged in order to serve anaerobic condition inside the reactor. The cycle was repeated for every 48 hours until all the reactors stabilizes, in which in this study the acclimatization stage took 90 days.

For each start-up, an initial microbial concentration in terms of mixed liquor suspended solid (MLVSS) was 13,000 mg-vSS/L, meanwhile the $\mathrm{pH}$ and total suspended solid (TSS) of the seed sludge sample was 4.6 and 14.9 g-SS/L, respectively.

\subsection{Studied wastewater}

The palm oil mill effluent POME wastewater was collected from Felda Bukit Besar Palm Oil Mill in Wilayah Bukit Besar, Johor Malaysia. Upon collection, the samples were preserved at temperature below $4^{\circ} \mathrm{C}$ to avoid biodegradation of the sample. The following Table 1 shows the characteristics of the studied wastewater.

Table 1: Characteristics of POME wastewater

\begin{tabular}{ll}
\hline Parameter & Concentration \\
\hline $\mathrm{pH}$ & 4.6 \\
$\mathrm{BOD}_{5}$ & $756 \mathrm{mg} / \mathrm{L}$ \\
$\mathrm{COD}$ & $239,000-431,500 \mathrm{mg} / \mathrm{L}$ \\
TSS & $5,500 \mathrm{mg} / \mathrm{L}$ \\
Ammoniacal Nitrogen & $30 \mathrm{mg} / \mathrm{L}$ \\
Nitrate & $895 \mathrm{mg} / \mathrm{L}$ \\
Nitrite & $2,000 \mathrm{mg} / \mathrm{L}$ \\
Sulfate & $1,050 \mathrm{mg} / \mathrm{L}$ \\
Sulfide & $6.0 \mathrm{mg} / \mathrm{L}$ \\
\hline
\end{tabular}

\section{$2.3 \quad$ Experiment setup}

The laboratory scale experimental setup consists of two units anaerobic digester (AD) of up-flow anaerobic sludge blanket (UASB) listed as AD1 and AD2; and a single-stage aerobic packed bed reactor. The schematic experimental setup was illustrated as in Figure 1.

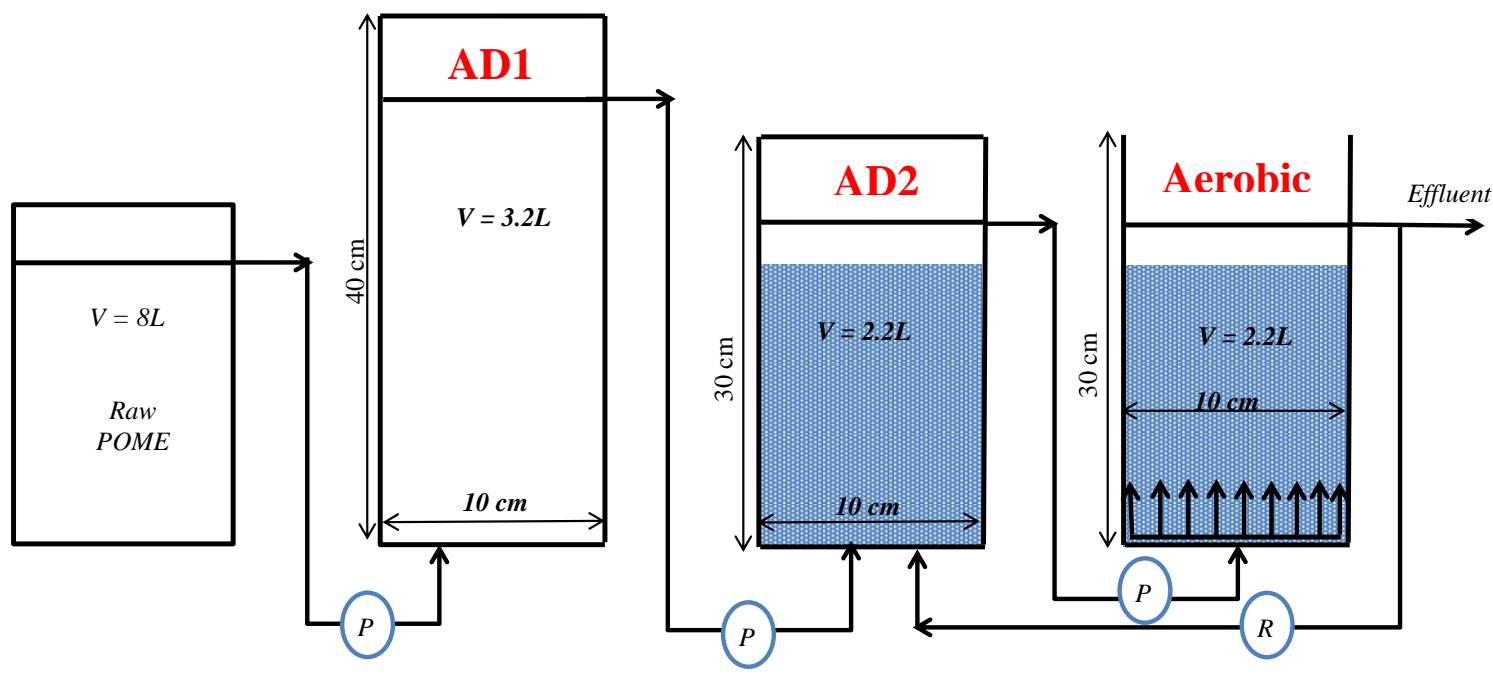

Figure 1: Schematic Diagram of Reactor Setup

In this system, AD1 reactor was fabricated with $100 \mathrm{~mm}$ and $400 \mathrm{~mm}$ in diameter and height, respectively; while both AD2 and aerobic reactor have $100 \mathrm{~mm}$ and $300 \mathrm{~mm}$ of diameter and height, respectively. Although AD1 and AD2 underwent the same type of treatment, the dimension of the $\mathrm{AD} 2$ was smaller compared to the AD1, however, it does not jeopardize the performance. This is because, the nutrients to the bacteria inside the AD2 reactor was adequate. The AD1 and AD2 were fabricated with both ends completely covered, while the aerobic reactor has appended with an air diffuser at the bottom of the reactor. In this study both AD2 and aerobic reactor was packed with polypropylene plastic media and has approximately 2.2L of liquid volume; whereasthe AD1 reactor has approximately about $3.2 \mathrm{~L}$ of liquid volume, with a headspace of $0.5 \mathrm{~L}$ for each reactor

\subsection{Integrated system operation and monitoring}

The two-stage UASB started to be integrated with an aerobic packed bed reactor once the biological stability was attained, which in this study after 90 days of operation with 48 hours of hydraulic retention time (HRT). During the operation of the integrated system, the AD1 reactor was fed with filtered fresh POME by using a peristaltic pump (Cole Parmer, USA), continuously at the flow rate of $1.6 \mathrm{~L} /$ day. The unfiltered POME can severely clog the tubing systems of the pumps. The effluent from the AD1 was fed directly into the AD2 reactor, while the effluent in AD2 reactor was pumpedinto the aerobic reactor. All the reactors possessed the same flowrate and HRT of $1.6 \mathrm{~L}$ and 48 hours, respectively throughout the operation. At the same time, the recirculation process also has been

employed from the aerobic reactor to the AD2 reactor, with a flow rate of $0.6 \mathrm{~L} /$ day. The performance of this integrated system was evaluated periodically based on COD and TSS until 150 days of operation.

\subsection{Measurements and analytical methods}

In order to monitor the performance of the entire integrated system, the COD and TSS concentration was monitored periodically. The COD concentration was determined by using the Hach High Range Plus, (200$15,000 \mathrm{mg} / \mathrm{L}$ COD) Reagents.while the TSS concentration by following the Method 2540B from the APHA Standard Method for the Examination of Water and Wastewater [17].

\section{RESULTS AND DISCUSSIONS}

The results were discussed in two sections, consists of the performance during the start-up phase and during the integrated phase.

\subsection{Start-up performance}

Figure 2 indicates the performance of a) COD and b) TSS in terms of percentage of removal (\%), for AD1, AD2 and aerobic reactor during the acclimatization phase. Based on Figure 2 a), the AD2 reactor shows excellent performance in removing COD, followed by aerobic and AD1 reactor with $87.3 \%, 41.8 \%$ and $34.3 \%$, respectively. This is happening due to the lower concentration of COD fed into both AD2 reactor and aerobic reactor compared to the AD1 reactor. Meanwhile, from the Figure $2 \mathrm{~b}$ ), it shows that negative removal of TSS was plotted from each reactor during the start-up. This is because of the acclimatization of substrates that lead to the increment of the sludge formation. On the other hand, the TSS concentration inside the aerobic reactor shows a decreasing pattern throughout the end of 90 days, indicates that removal of sludge start to occur. 

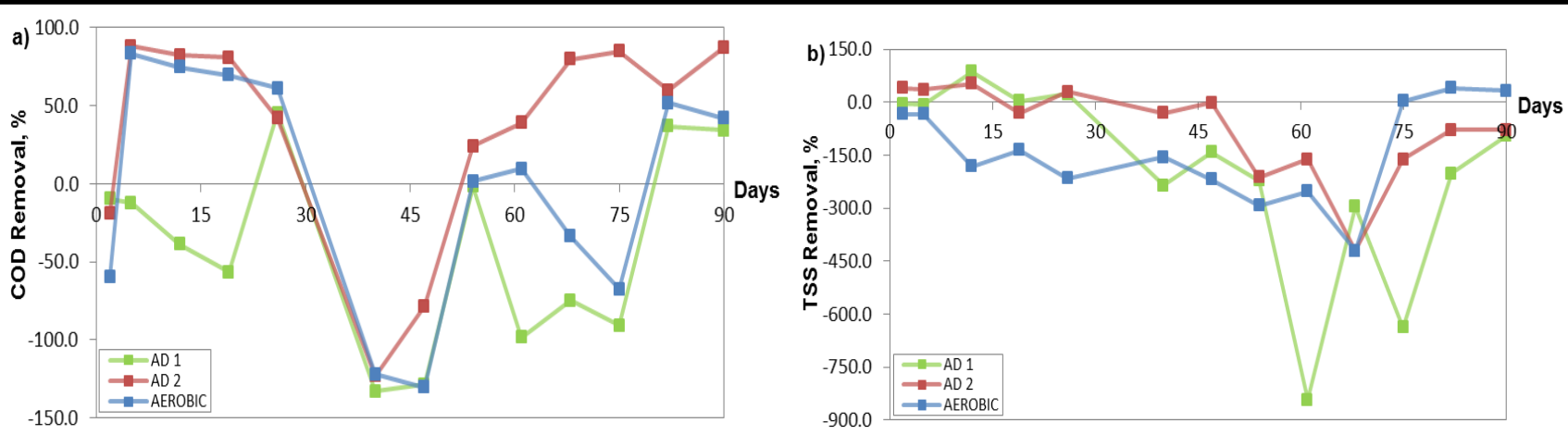

Figure 2: a) COD; and b) TSS Removal during the Start-up Process

3.2 Integrated system performance

Figure 3 (a) and (b) depicts the COD and TSS removal efficiency of the entire integrated system, respectively.
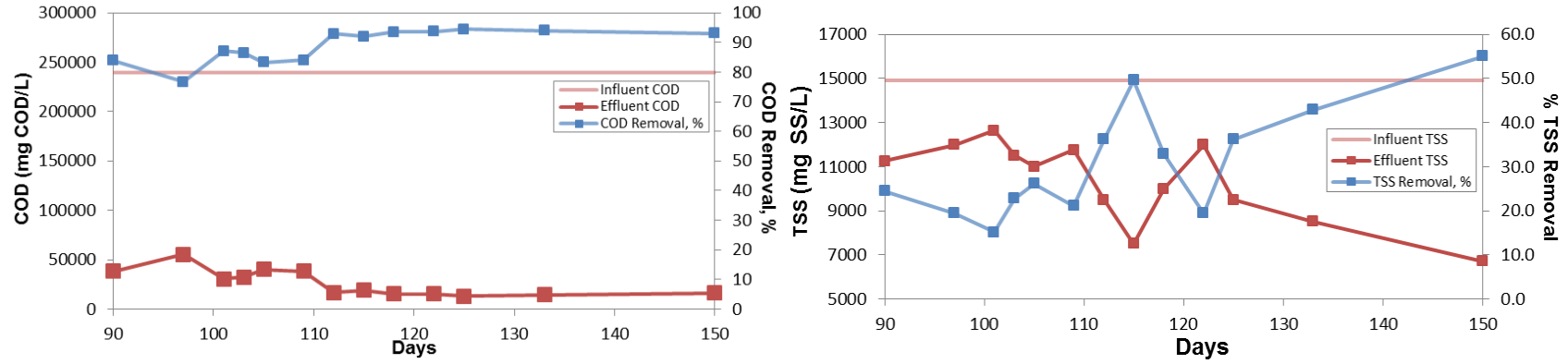

Figure 3: a) COD; and b) TSS Removal during the Integrated System

Referred to the Figure 3.a), excellent performance of the system was recorded, which approximately $92 \%$ to $94.5 \%$ of COD removal was attained. At the end of 150 days of operation, the effluent concentration of COD of the integrated system was $16,450 \mathrm{mg}-\mathrm{COD} / \mathrm{L}$, indicates about $93 \%$ of COD reduction were achieved. On top of that, despite of using fresh POME in this study, which have high influent COD concentration, this system able to performed efficiently.

Meanwhile, from the Figure 3.b), the fluctuating trend was spotted from the profile, shows about $15 \%$ to $55 \%$ of TSS removal was accomplished. At the end of the experiment operational days, the effluent TSS concentration was $6,700 \mathrm{mg}$-SS/L, with $55 \%$ of SS reduction. However, further study on this implemented principle on treating sludge reduction is vital in order to improve the performance of removal efficiency.

\section{CONCLUSIONS}

Throughout this study, the following conclusions were enclosed:

1. The principle of the two-stage anaerobic coupled with single stage aerobic process in treating fresh raw POME was successfully applied in this study. Throughout this study, satisfactory reduction of COD and TSS was attained, implying this integrated system was competent in treating high strength wastewater. However, further research need to be made to ensure the stability consistency and feasibility of this integrated system.

2. Through the acclimatization stage, negative removal of TSS was spotted from each of the reactor. This is due to the acclimatization of the substrates during the start-up period. Meanwhile, the AD2 reactor shows a better COD removal performance followed by aerobic and AD1 reactor, which $87.3 \%, 41.8 \%$ and $34.3 \%$, respectively, was attained during the start-up period.

3. During the integration phase, COD shows a stable trend of profile ranged about $92-94 \%$ of removal. At the same time, the SS profile plotted a fluctuated trend ranged between $15 \%$ to $55 \%$ of removal.

4. At the end of the 150 days of operating period, excellent removal efficiency of COD and SS was achieved with $93 \%$ and $55 \%$ of removal, respectively.

\section{ACKNOWLEDGEMENTS}

The authors would like to thank Felda Bukit Besar, Wilayah Bukit Besar,
Johor, Malaysia for providing wastewater and seed sludge and the Potential Academic Staff Grant from Universiti Teknologi Malaysia for

providing financial support forthis research. The staffs and technicians of Environmental Engineering Laboratory, under Department of Environmental Engineering, Universiti Teknologi Malaysia Johor Bharu, Malaysia are also acknowledged.

\section{REFERENCES}

[1] MPOB. 2017. Malaysian Oil Palm Statistics 2016, 36th Ed. Economics And Industry Development Division, Malaysian Palm Oil Board, Malaysia.

[2] Chan, Y.J., Chong, M.F., Law, C.L. 2012. An Integrated AnaerobicAerobic Bioreactor (Iaab) For The Treatment Of Palm Oil Mill Effluent (Pome): Start-Up And Steady State Performance. Process Biochemistry, 47 (3), 485-495.

[3] Chan, Y.J., Chong, M.F., Law, C.L. 2013. Optimization Of Palm Oil Mill Effluent Treatment In An Integrated Anaerobic-Aerobic Bioreactor. Sustainable Environment Research, 23 (3), 153-170.

[4] Chan, Y.J., Chong, M.F., Law, C.L. 2017. Performance And Kinetic Evaluation of An Integrated Anaerobic-Aerobic Bioreactor In The Treatment Of Palm Oil Mill Effluent. Environmental Technology, 38 (8), 1005-1021.

[5] Chan, Y.J., Chong, M.F., Law, C.L., Hassell, D. 2009. A Review On Anaerobic-Aerobic Treatment Of Industrial And Municipal Wastewater. Chemical Engineering Journal, 155 (1-2), 1-18.

[6] Wang, R.M., Wang, Y., Ma, G.P., He, Y.F., Zhao, Y.Q. 2009. Efficiency Of Porous Burnt-Coke Carrier On Treatment Of Potato Starch Wastewater With An Anaerobic-Aerobic Bioreactor. Chemical Engineering Journal, 148 (1), 35-40.

[7] Baranitharan, E., Khan, M. R., Prasad, D. 2013. Treatment Of Palm Oil Mill Effluent In Microbial Fuel Cell Using Polyacrylonitrile Carbon Felt As Electrode. Journal Of Medical And Bioengineering, 2 (4), 252-256.

[8] Taha, M.R., Ibrahim, A.H. 2014. Cod Removal From Anaerobically Treated Palm Oil Mill Effluent (At-Pome) Via Aerated Heterogeneous Fenton Process: Optimization Study. Journal Of Water Process Engineering, 1, 8-16. 
[9] Soleimaninanadegani, M., Manshad, S. 2014. Enhancement of Biodegradation Of Palm Oil Mill Effluents By Local Isolated Microorganisms. International Scholarly Research Notices. http://dx.doi.org/10.1155/2014/727049

[10] Choi, W.H., Shin, C.H., Son, S.M., Ghorpade, P.A., Kim, J.J., Park, J.Y. 2013. Anaerobic Treatment Of Palm Oil Mill Effluent Using Combined High-Rate Anaerobic Reactors. Bioresource Technology, 141, 138-144.

[11] Jeong, J.Y., Son, S.M., Pyon, J.H., Park, J.Y. 2014. Performance Comparison Between Mesophilic And Thermophilic Anaerobic Reactors For Treatment Of Palm Oil Mill Effluent. Bioresource Technology, 165, 122-128.

[12] Mamimin, C., Singkhala, A., Kongjan, P., Suraraksa, B., Prasertsan, P., Imai, T., O-Thong, S. 2015. Two-Stage Thermophilic Fermentation And Mesophilic Methanogen Process For Biohythane Production From Palm Oil Mill Effluent. International Journal Of Hydrogen Energy, 40 (19), 63196328.
[13] Krishnan, S., Singh, L., Sakinah, M., Thakur, S., Wahid, Z.A., Alkasrawi M. 2016. Process Enhancement Of Hydrogen And Methane Production From Palm Oil Mill Effluent Using Two-Stage Thermophilic And Mesophilic Fermentation. International Journal Of Hydrogen Energy, 41 (30), 1288812898.

[14] Azbar, N., Speece, R.E. 2001. Two-Phase, Two-Stage, And SingleStage Anaerobic Process Comparison. Journal Of Environmental Engineering, 127, 240-248.

[15] Cuetos, M.J., Gómez, X., Escapa, A., Morán, A. 2007. Evaluation And Simultaneous Optimization Of Bio-Hydrogen Production Using 32 Factorial Design And The Desirability Function. Journal Of Power Sources, 169 (1), 131-139.

[16] Hidalgo, D., Martín-Marroquín, J.M., Sastre, E. 2014. Single-Phase And Two-Phase Anaerobic Co-Digestion Of Residues From The Treatment Process Of Waste Vegetable Oil And Pig Manure. Bioenergy Research, 7 (2), 670-680.

[17] APHA. 2005. Standard Methods For The Examination Of Water And Wastewater 21th Ed Washington, Dc.: American Public Health Association.

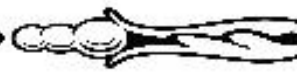

